\title{
Dissent from the Homeland: Essays after September 11
}

Stanley Hauerwas and Frank Lentricchia, special issue editors

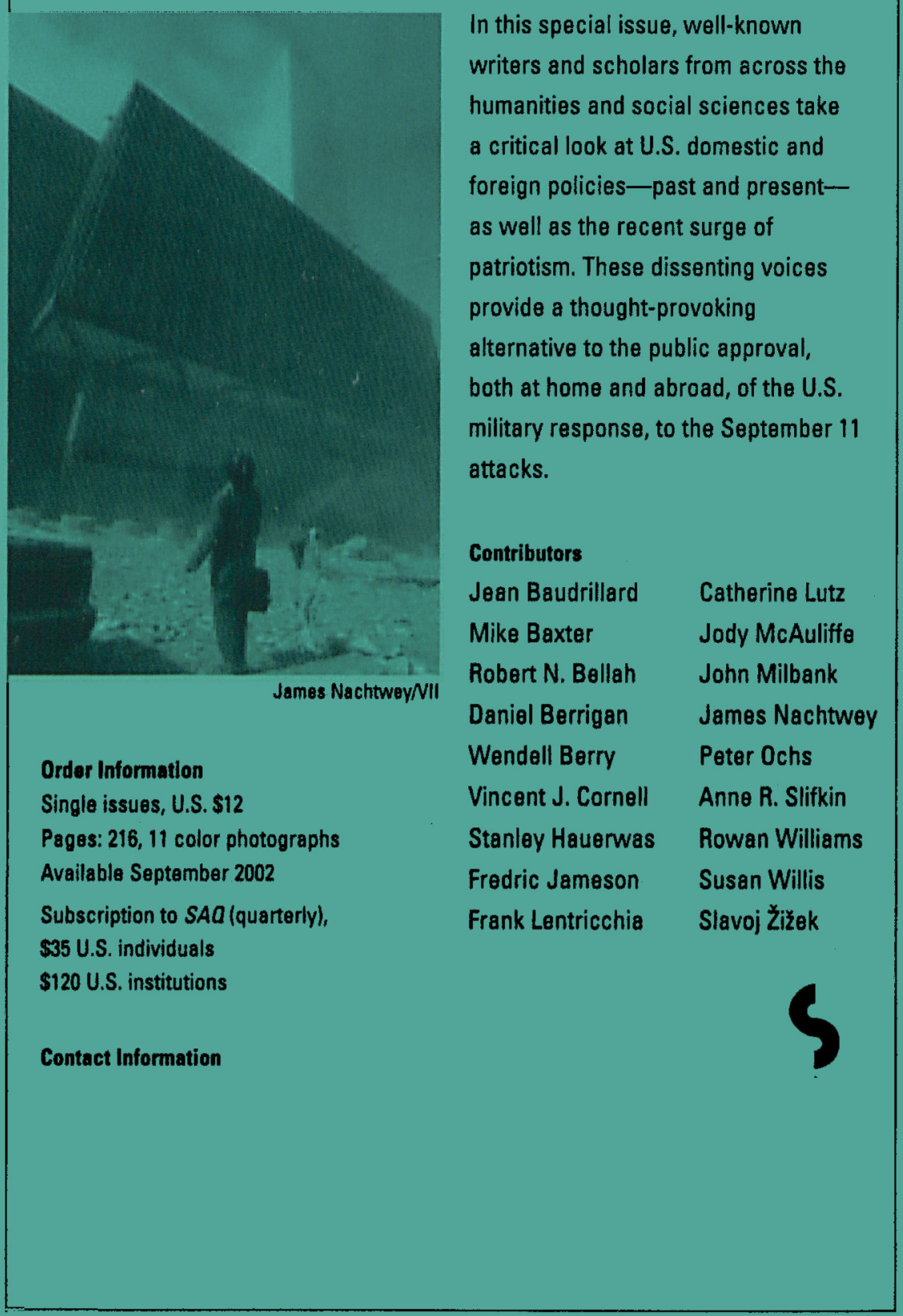

